\title{
Surface Roughness Values of Magnesium Alloy AZ31 When Turning by Using Rotary Cutting Tool
}

\author{
Gusri Akhyar ${ }^{1, *}$, Suryadiwansa Harun ${ }^{1}$, Arinal Hamni ${ }^{1}$
}

\begin{abstract}
Magnesium and magnesium alloys is one of materials that worldwide used on automotive components due to very good strength to weight ratio, resistant to corrosion, lighter compare to steel materials. Other than that magnesium has an advantage in easy to form and good machinability. Nevertheless, magnesium known as metal which is easy to burned because of magnesium has low melting point. To maintain magnesium from burning quickly when proses machining, it needs to use coolant or lubricant to reduce temperature. Using of coolant when machining process can reduce temperature on cutting tool and work piece material, while using of lubricant can reduce friction between the cutting tool and work piece mateial. However, using of coolant and lubricant can harm for the environment and also coolant difficult to destroyed. Therefore, an alternative method to reduce the temperature when machining of magnesium alloy is using the rotary cutting tool system. In the rotary cutting tool system, the cutting tool has a time to experience cooling in the period time. Other than aspect of temperature, surface roughness values are representative of surface of quality of produced componens. In this research, surface roughness value of magnesium alloy of AZ31 observed in ranges of work piece cutting speed of (Vw) $25,50,120,160,200 \mathrm{~m} / \mathrm{min}$, rotary cutting speed of $(\mathrm{Vt}) 25$, $50,75 \mathrm{~m} / \mathrm{min}$, feed rate of (f) 0,05 and $0,10 \mathrm{~mm} / \mathrm{rev}$, and depth of cut of $0.2 \mathrm{~mm}$. The turning process was done by using two kinds of diameter of rotary cutting tools are 16 and $20 \mathrm{~mm}$, and without applying of coolant. The results of the research showed that the minimum surface roughness value of machined surface was $0,62 \mu \mathrm{m}$ by using insert with diameter of $16 \mathrm{~mm}$, while the maximum surface roughness value of machined surface was $2,86 \mu \mathrm{m}$ by using insert with diameter of $20 \mathrm{~mm}$. This result stated that the increase in the diameter of rotary cutting tool gives a significant effect on the produced surface roughness value. Factor of feed rate also gives a significant contribution on the surface roughness value of machined magnesium surface. The increase in feed rate generated significantly surface roughness value as long as the trials experiments. The produced surface roughness values inversely proportional to the cutting speed of rotary cutting tool.
\end{abstract}

Keywords - magnesium, rotary tool, surface roughness, turning.

\section{INTRODUCTION}

The magnesium alloy are currently the lightest alloys used as green structural materials. As the lightest materials, magnesium has density of $1.8 \mathrm{~g} / \mathrm{cm}^{3}$, and its lower than others metals as like steel and aluminium. Advantages of magnesium alloys such as excellent mechanical properties, good machinability, good electromagnetic, shielding characteristic, high dimensional

${ }^{1}$ Department of Mechanical Engineering, Faculty of Engineering, Universitas Lampung, Gedung H, Lt 2, Jalan Prof. Soemantri Brojonegoro No. 1, Bandar Lampung, Indonesia.

email: gusri.akhyar@eng.unila.ac.id, suryadiwansa.harun@eng.unila.ac.id, arinal.hamni@yahoo.com stability, high strength to weight ratio, high stiffness to weight ratio and high resistant corrosion. Therefore, magnesium alloys are currently used in wide range of applications in electronic, automotive, aerospace industries and biomedical materials (International magnesium, 1989; Bai et al, 2006).

However, the magnesium alloys also known as easy flammable material due to it has low melting point $\left(400-600^{\circ} \mathrm{C}\right)$. In the machining process, magnesium alloys have a good cutting characteristic, low specific cutting strength, short chip length, low tool wear progression, good surface integrity and cutting in high cutting speed. Compare to other metals, the magnesium alloys can be cut by lower cutting energy [1]

As known that to decrease cutting temperature of machining process can be done by using coolants or lubricants. Still in development, using fluids cutting were minimalized, due to its harmful for operator's health, contaminate environmental and increase cost production. The cost to degradable cutting fluids is higher than the nominal cost of cutting fluids. Some treatments are needed to dispose the waste of cutting fluid to normalize chemical composition in the cutting fluid [2].

Some attempts have been done to develop the machining process, to produce good cutting tool performance and surface integrity of machined surface. Implemented strategy to eliminate cutting fluids is machining without the cutting fluids or dry machining. In term of manufacturing, dry machining as known as green machining. Dry machining is also mean as cutting using cool air with high pressure. This method implemented aims to reduce the cost production, increase the productivity and friendly to environment [3].

Anyhow, the dry machining condition has a basic problem is high generated temperature at the cutting tool and also at the machined surface. The high temperature generated between the cutting tool and machined surface tend to cause damage on the surface and inaccurate of dimension. By all means, the damage on machined surface has effected on the quality of product. Mahayatra [4] stated that the surface roughness value in the dry machining was shown higher than the machining at using cutting fluid. It can be concluded that the surface quality was affected by the cutting tool temperature.

One of methods to reduce the generated temperature between the cutting tool and work piece was an implementation of rotary cutting tool [1,5]. Advantage of using the rotary cutting tool is low cutting temperature because of the cutting tool rotate during machining process. There is time to get cooling down for a moment before continuing the cutting [6].

During a period of cutting, there is a time not contact to work piece. It is time to cool the cutting edge of tool. In addition to the wear of cutting tool, the surface roughness value of machined surface also contribute significantly to quality of products. It's due to the surface roughness becomes 
a characteristic to determine the surface quality of products [6]. Therefore, this research aims to investigate the surface roughness values of AZ31 of magnesium alloy which was turned by using the rotary cutting tools.

\section{RESEARCH METHODOLOGY}

The research took place at the Laboratory production of Engineering Faculty of Lampung University. Material used in the experiment was magnesium alloy AZ31, which has 3\% of aluminium and $1 \%$ of zinc. The detail physical properties of magnesium alloy AZ31 as shown in Table 1. Machining trials were done by using the conventional turning of Pinacho as shown in Fig. 1. The rotary cutting tools were implemented with diameter insert of $16 \mathrm{~mm}$ and $20 \mathrm{~mm}$.

Table 1. Ph ysical properties of magnesium alloy az31

\begin{tabular}{ll}
\hline \hline Melting point, ${ }^{\circ} \mathbf{K}$ & $\mathbf{9 2 2}$ \\
\hline Boiling point, ${ }^{\circ} \mathrm{K}$ & 1380 \\
Ionization energy I, kJ/mol & 738 \\
Ionization energy II, kJ/mol & 1450 \\
Density, g/cm ${ }^{3}$ & 1,74 \\
Radius of atom, A & 1,60 \\
Heat capacity, $\mathrm{J} / \mathrm{gK}$ & 1,02 \\
Ionization potential, volt & 7,646 \\
Enthalpi vaporization, kJ/mol & 127,6 \\
Heat conductivity, W/mK & 156 \\
Enthalpy of formation, $\mathrm{kJ} / \mathrm{mo}$ & 8,95 \\
\hline \hline
\end{tabular}

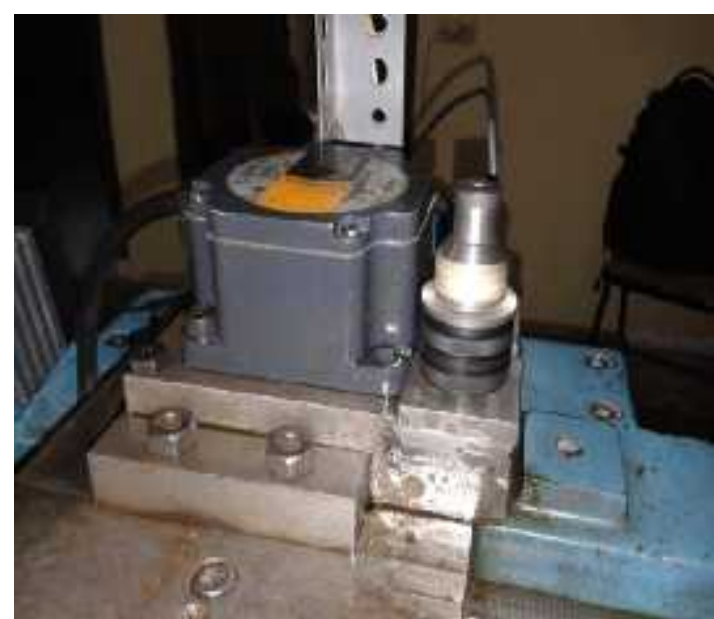

Fig. 1.Rotary cutting tool system which attached on lathe machine
Table 2. Detail specification of the rotary cutting tool

\begin{tabular}{ll}
\hline \hline Motor merk & Axum590-A \\
\hline Insert type & Insert propeller \\
Tool material & PVD coated cermets \\
Rotation speed & $0-2000 \mathrm{rpm}$ \\
Rotation direction & $\mathrm{CCW}$ \\
Insert diameter & 16 and $20 \mathrm{~mm}$ \\
\hline \hline
\end{tabular}

The cutting parameters evaluated in this experiment were rotation of work piece $\left(\mathrm{v}_{\mathrm{w}}\right)$, feed rate (f), dept of cut (d), and rotation of rotary tool $\left(\mathrm{v}_{\mathrm{t}}\right)$. Each parameter consists of some levels as shown in Table 3. The speed of work piece is a factor that gives a dominant contribution on generated temperature when machining super light alloy. So it is more levels need to investigate.

Tabel 3.Variasi of cutting parameters

\begin{tabular}{ll}
\hline \hline Workpiece speed $\left(\mathrm{v}_{\mathbf{w}}\right) \mathrm{m} / \mathbf{m i n}$ & $\begin{array}{l}\mathbf{2 5}, \mathbf{5 0 , \mathbf { 1 2 0 } ,} \\
\mathbf{1 6 0} \text { and } \mathbf{2 0 0}\end{array}$ \\
\hline Depth of cut $(\mathrm{d}) \mathrm{mm}$ & 0,2 \\
Feed rate $(\mathrm{f}) \mathrm{mm} / \mathrm{rev}$ & 0,05 and 0,10 \\
Tool speed $\left(\mathrm{v}_{\mathrm{t}}\right)$ & 25,50 and 75 \\
\hline
\end{tabular}

Turning trials were done to measure wear land of flank face of the cutting tools, whereas surface roughness values were measured to study surface quality of machined surface. The flank wear of insert was recorded by using USB microscope with magnification by $50 \mathrm{x}$, and the surface roughness of machine surface was measured by using surface roughness tester with accurate level of $0,01 . \mu \mathrm{m}$. Every one interval machining, measuring the cutting time and surface roughness were done. The machining was stopped when the wear land has reached $\mathrm{Vb} 0,2 \mathrm{~mm}$.

\section{RESUlts AND Discussions}

Effect of rotary tool speed on the surface roughness values

The experiments were conducted on magnesium alloy AZ31 by using a conventional lathe machine with the rotary cutting tool. Surface roughness values were recorded by using the surface roughness tester at work piece speed of 25, 50, 120,160 and $200 \mathrm{~m} / \mathrm{min}$; cutting tool speed of 25,50 and 75 $\mathrm{m} / \mathrm{min}$; feed rate of 0.05 and $0.10 \mathrm{~mm} / \mathrm{rev}$ and depth of cut remains constant. The type of the rotary tools with diameter of $16 \mathrm{~mm}$ was used to record the surface roughness values.

The surface roughness values of machined surface were significant influenced by speed of rotary tool. It can be seen at Fig. 2 that, generally, at lower speed of rotary tool result 
higher surface roughness values. At speed of rotary tool of 5 $\mathrm{m} / \mathrm{min}$, surface roughness value was $1.88 \mu \mathrm{m}$, whereas at speed of rotary tool of $75 \mathrm{~m} / \mathrm{min}$ was $1.23 \mu \mathrm{m}$. There is $35 \%$ of decreasing of surface roughness value. Similar condition also occurred at work speed of $75 \mathrm{~m} / \mathrm{min}, 120 \mathrm{~m} / \mathrm{min}$ and 160 $\mathrm{m} / \mathrm{min}$. The decreasing of surface roughness at the higher speed rotary tool was caused by effect of cutting speed when machining process. As mentioned by previous research that the cutting speed has a significant contribution on the surface roughness value, especially at high cutting speed [7].As shown at Fig 2(d) that the decreasing of surface roughness reached $38 \%$ for feed rate of $0.10 \mathrm{~mm} / \mathrm{rev}$ and $30 \%$ for feed rate of $0.05 \mathrm{~mm} / \mathrm{rev}$. More than $30 \%$ of reducing the surface roughness value as effect of speed or rotary tool. Therefore, it can be declared that the speed of rotary tool gave a dominant contribution on the surface roughness value when machining of magnesium alloy using carbide tools.
However, the contradicted results found at work piece speed of $200 \mathrm{~m} / \mathrm{min}$, in which the surface roughness value increased with increasing of speed of rotary tool. Fig. 2(c)also shows an increase of surface roughness at speed of rotary tool of $50 \mathrm{~m} / \mathrm{min}$ and $75 \mathrm{~m} / \mathrm{min}$. The increase surface roughness at speed of rotary tool of $50 / \mathrm{min}$ is lower than at speed of rotary tool of $75 \mathrm{~m} / \mathrm{min}$. At speed of rotary tool of $50 \mathrm{~m} / \mathrm{min}$, the increase of the surface roughness reached $6.1 \%$, meanwhile at speed of rotary tool of $75 \mathrm{~m} / \mathrm{min}$, the increase of the surface roughness reached $23.6 \%$. It can be concluded that at high speed of rotary tool generated high surface roughness value too. However, this result only occurred at work piece speed of $200 \mathrm{~m} / \mathrm{min}$. It is possible caused by change of geometry tool after machining process. The rotary cutting speed experienced worn on the cutting edge.

Table 4. Surface roughness values recorded at feed rate (f) of 0.05 and $0.10 \mathrm{~mm} / \mathrm{rev}$. with diameter of insert of $16 \mathrm{~mm}$ and depth of cut $0.20 \mathrm{~mm}$.

\begin{tabular}{|c|c|c|c|c|c|}
\hline $\begin{array}{c}\begin{array}{c}\text { Work piece } \\
\text { speed }\end{array} \\
\text { Vw m/min }\end{array}$ & $\begin{array}{c}\text { Cutting tool } \\
\text { speed } \\
\text { Vt } \mathbf{~ m} / \mathbf{m i n}\end{array}$ & $\begin{array}{l}\text { Feed rate, } \\
\text { F mm/rev }\end{array}$ & $\begin{array}{c}\text { Surface } \\
\text { Roughness } \\
\text { Ra } \mu \mathrm{m}\end{array}$ & $\begin{array}{l}\text { Feed rate, } \\
\text { F mm/rev }\end{array}$ & $\begin{array}{c}\text { Surface } \\
\text { Roughness } \\
\text { Ra } \mu \mathrm{m}\end{array}$ \\
\hline \multirow[t]{3}{*}{25} & 25 & 0.05 & 1.18 & 0.1 & 1.88 \\
\hline & 50 & & 0.84 & & 1.43 \\
\hline & 75 & & 0.75 & & 1.23 \\
\hline \multirow[t]{3}{*}{50} & 25 & 0.05 & 1.28 & 0.1 & 1.69 \\
\hline & 50 & & 0.86 & & 1.19 \\
\hline & 75 & & 0.88 & & 1.14 \\
\hline \multirow[t]{3}{*}{120} & 25 & 0.05 & 1.49 & 0.1 & 1.67 \\
\hline & 50 & & 1.12 & & 1.24 \\
\hline & 75 & & 1.15 & & 1.29 \\
\hline \multirow[t]{3}{*}{160} & 25 & 0.05 & 1.4 & 0.1 & 1.98 \\
\hline & 50 & & 1.14 & & 1.52 \\
\hline & 75 & & 0.98 & & 1.23 \\
\hline \multirow[t]{3}{*}{200} & 25 & 0.05 & 1.37 & 0.1 & 1.63 \\
\hline & 50 & & 1.46 & & 1.71 \\
\hline & 75 & & 1.91 & & 2.09 \\
\hline
\end{tabular}



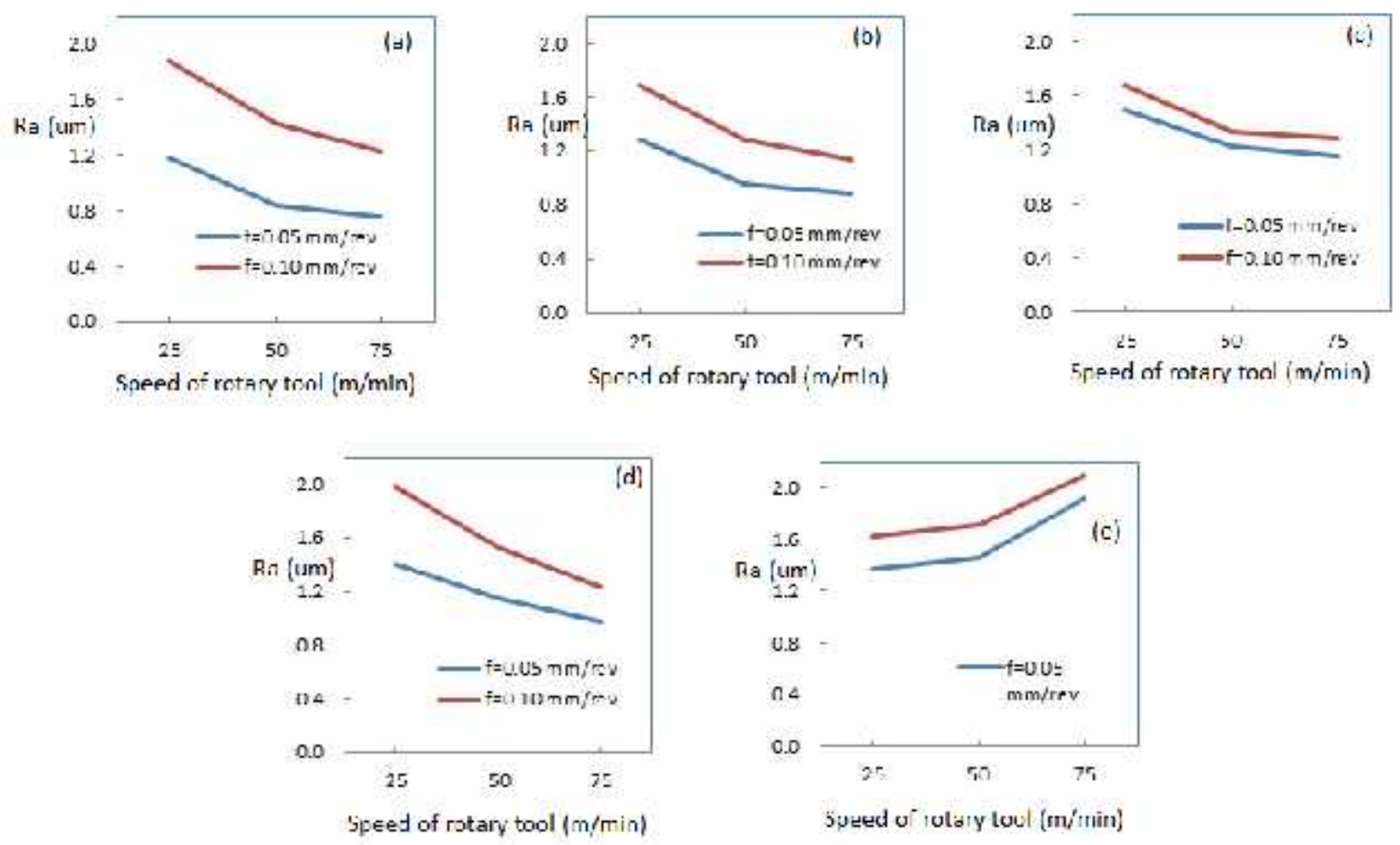

Fig. 2. The effect of speed of rotary tool on the surface roughness values using diameter tool of $16 \mathrm{~mm}$ and at various of work piece speed: (a) $25 \mathrm{~m} / \mathrm{min}$, (b) $50 \mathrm{~m} / \mathrm{min}$, (c) $120 \mathrm{~m} / \mathrm{min}$, (d) $160 \mathrm{~m} / \mathrm{min}$ and (e) $200 \mathrm{~m} / \mathrm{min}$.

\section{Effect of feed rate on the surface roughness values}

Fig. 3 shows surface roughness values recorded when machining magnesium alloy by using carbide tool at various work piece speed with diameter of rotary tool of $16 \mathrm{~mm}$. It can be also seen at Fig 3 that the effect of feed rate on the surface roughness values at between feed rate of $0.05 \mathrm{~mm} / \mathrm{rev}$ and $0.10 \mathrm{~mm} / \mathrm{rev}$. Generally, Fig. 3(a) - 3(d) show the surface roughness values increase significantly from feed rate 0.05 $\mathrm{mm} / \mathrm{rev}$ to feed rate $0.10 \mathrm{~mm} / \mathrm{rev}$. At Fig 3(a), the surface roughness value increases to $37.3 \%$, if increasing of feed rate from $0.05 \mathrm{~mm} / \mathrm{rev}$ to $0.10 \mathrm{~mm} / \mathrm{rev}$. It result was found at the work piece speed of $25 \mathrm{~m} / \mathrm{min}$. Meanwhile, similar result also found when machining at the work piece speed of $50 \mathrm{~m} / \mathrm{min}$. Theoretically, the feed rate gives a significant contribution on the surface roughness value. Selection of high feed rate factor when machining super alloy material generated high machined surface [8]. The feed rate directly effect on feed mark at the machined surface. Beside of the feed rate, wear on the tool surface also contribute on the feed mark on the new machined surface [9]. 

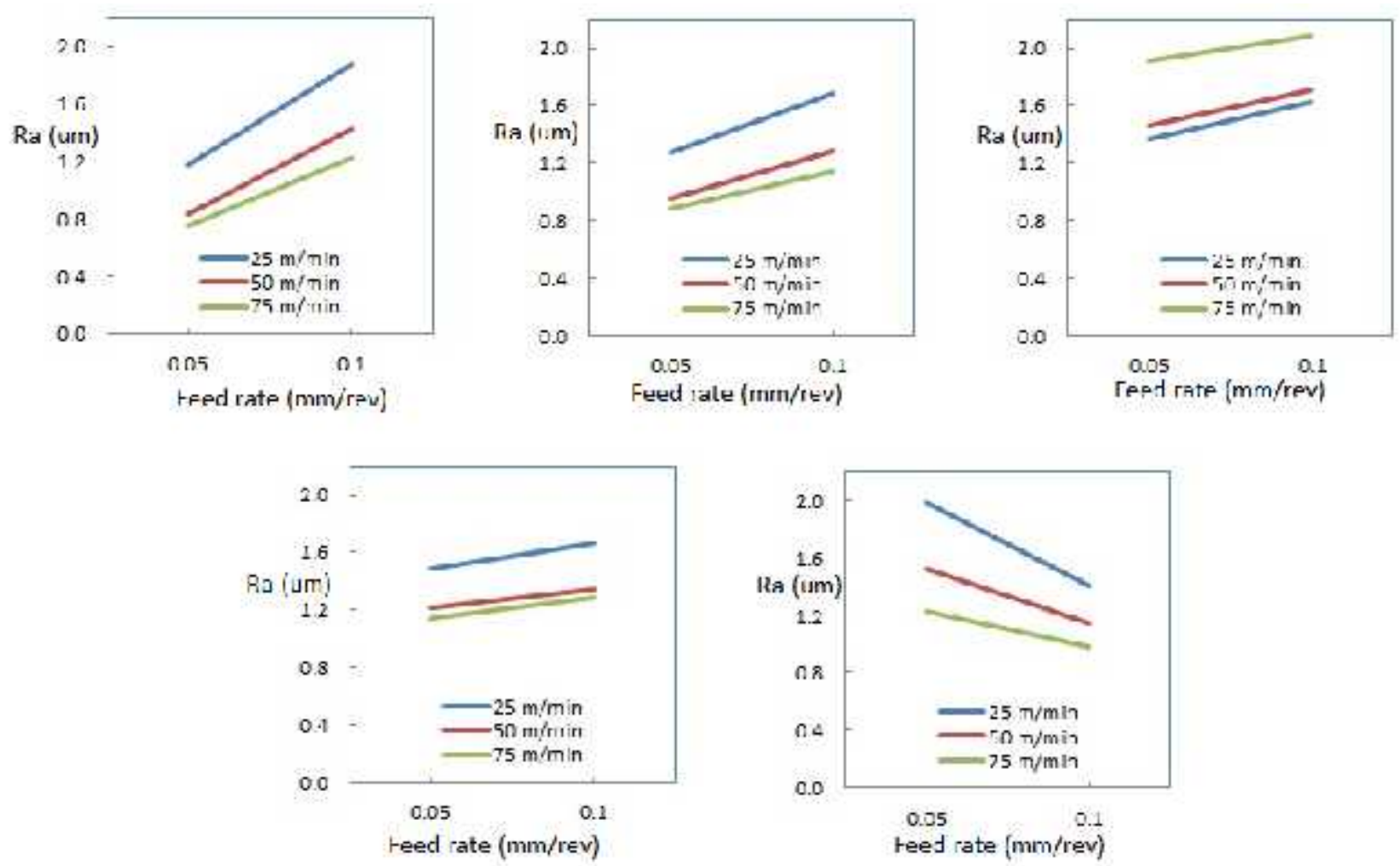

Fig. 3 .The effect of the feed rate (f) on the surface roughness values at various tool speed with diameter tool of $16 \mathrm{~mm}:$ : (a) $25 \mathrm{~m} / \mathrm{min}$, (b) $50 \mathrm{~m} / \mathrm{min}$, (c) 120 $\mathrm{m} / \mathrm{min}$, (d) $160 \mathrm{~m} / \mathrm{min}$ and (e) $200 \mathrm{~m} / \mathrm{min}$

Feed marks on the machined surface of magnesium alloy after machining

The profile of machined surface of magnesium alloy AZ31 which was machined by using the carbide tool with diameter of $16 \mathrm{~mm}$ was shown in Fig. 4. The cutting parameters used in the cutting were at feed rate of 0.05 $\mathrm{mm} / \mathrm{rev}$ and work piece speed of $35 \mathrm{~m} / \mathrm{min}$. Feed mark on the top surface is a result of feeding parameter. The feed rate parameter has strong correlation to surface texture. As stated by previous researcher that nose radius and feed rate have a significant correlation to surface texture of new machined surface when machining super alloy materials [10]. Meanwhile, Gusri, et.al [9] found that when machining super alloy material, surface texture of machined surface formed were affected by worm tool.
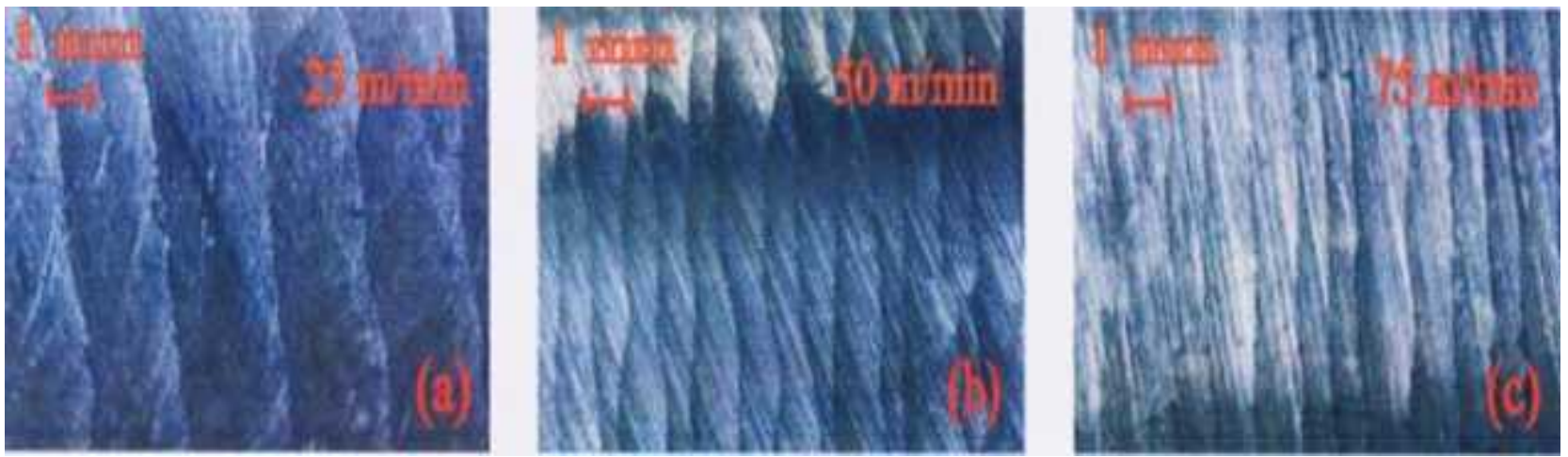

Fig. 4.The surface texture of machined surface when machining of magnesium AZ31 by using carbide tool with diameter of $16 \mathrm{~mm}$.

\section{CONCLUSION}

The speed of rotary tool contributed sigficantly on the surface roughness value when machining magnesium AZ31 by using carbide tool with diameter of $16 \mathrm{~mm}$.
Generally, at low speed of rotary tool result higher surface roughness values. There is $35 \%$ of decreasing of surface roughness while machining at speed of rotary tool of $75 \mathrm{~m} / \mathrm{min}$. At speed of rotary tool of $200 \mathrm{~m} / \mathrm{min}$, 
the surface roughness value increased with increasing of speed of rotary tool. The maximum increase of the surface roughness reached $23.6 \%$ at speed rotary tool of $75 \mathrm{~m} / \mathrm{min}$. The surface roughness value increased significantly by increasing the feed rate from 0.05 $\mathrm{mm} / \mathrm{rev}$ to $0.10 \mathrm{~mm} / \mathrm{rev}$, even the increasing reached to $37.3 \%$.

\section{REFERENCES}

[1] S. Harun, "Cutting Temperature Measurement in Turning with ActivelyDriven Rotary Tool,".Key Engineering Materials, Vol. 389-390, pp. 138-142, 2009.

[2] V. Kauppinen,"Environmentally reducing of coolant in mtal cutting,proceedings University's Days $8^{\text {th }}$ International Conference," Helsinki University of Tchnology, 2002.

[3] S. Koudri, K. Necip, S. Atlati, . M. Nouari, "Qualification of the chip segmentation in metal machining: Applicatio to machining the aeronautical aluminium alloy AA2024- T351 with cemented carbide tools WC-Co," International Journal of Machine Tools \& Manufacture, Vol. 64, pp. 102 - 113, 2013.
[4] P.S., Srejith, B.K.A., Ngoi, "Dry machining: Machining of the future, Journal of Manufacture and Processing Technology," Vol. 101, pp. 287 - 291, 2002.

[5] A. Darmanto, I. Zubaidi,Syafa'at., "Analisi Pengaruh Kecepatan Putar Dan Kcepatan Pemakanan Terhadap Kekerasan Prmukaan MaterialPada Mesin Bubut," Universitas Wahid Hasyim, Semarang, 2002.

[6] M.T. Wang, H.Y. Chou, "Risk Allocation and Risk Handling of Handling of Highway Projects in Taiwan," Journal of Management in Engineering, ASCE, 2003.

[7] G.A. Ibrahim, C.H.C. Haron, J.A. Ghani, A.Y.M. Said, M.Z.A. Yazid, 2011 "Performance of PVD coated carbide tools when turning inconel 718 in dry machining," Advanced in Mechanical Engineerin, 2011.

[8] S., Kalpakjian and S.R., Rcmid, "Manufacturing engineering and technology fourth edition," USA, Prentice Hall, 2006.

[9] G.A. Ibrahim, C.H. Che Haron, J.A. Ghani, "Tool wear mechanism in continuous cutting of difficult-to-cut material under dry machining,"Advanced Materials Research, Vol 126-128, pp. 195-201, 2010.

[10] S.E., Henderson, K. Verdelis, S. Maiti, S. Pal, W.L., Chung, D.R., Chou, P.N., Kumta, A.J., Almarza, "Magnesium alloys as a biomaterial for degredable craniofacial screws," Acta Biomaterialia, vol. 10, pp. 2323-2332, 2014. 